\title{
Influence of polymeric derivatives of guanidine on hydrobionts
}

Andriy Lysytsya ${ }^{1 *}$,

Natalya Matvienko²,

Mihail Kozii' ${ }^{3}$,

Alexander Aishpur ${ }^{4}$

${ }^{1}$ Department of Ecology,

Rivne State University of Humanities,

Plastova St. 29a-203,

Rivne 33028, Ukraine

${ }^{2}$ Institute of Fisheries of

the National Academy

of Agrarian Sciences,

Obukhivska St. 135,

Kiev 03164, Ukraine

${ }^{3}$ Petro Mohyla Black

Sea National University, 10,

68-Desantnykiv Steet,

Mykolayiv oblast,

Mykolayiv 54003, Ukraine

${ }^{4}$ National University

of Life and Environmental

Sciences of Ukraine,

Heroyiv Oborony St. 15,

Kyiv 03041, Ukraine
It is known that polymeric derivatives of guanidine are actively used in many countries of the world as disinfectants and antiseptics. Polyhexamethylene guanidine (PHMG) and polyhexamethylene biguanidine (PHMB) are typical representatives of this class of compounds. They show a bacteriostatic effect in concentrations from $1 \mathrm{mg} / \mathrm{l}$ (or $10^{-4} \%$ ) or above, and a bactericidal effect from $10 \mathrm{mg} / \mathrm{l}\left(10^{-3} \%\right)$ and above. It is considered that PHMG and PHMB are not very toxic to higher organisms. This is explained by the different mechanism of drugs action on prokaryotic and eukaryotic cells. However, their safety for the fauna of freshwater hydrocenoses has not been sufficiently studied.

The toxic effect of the salts of PHMG on the representatives of various types and classes of hydrobionts was studied in the experiments.

It has been established that the safe concentration of PHMG in water with a one-time action on selected test objects is $0.1 \mathrm{mg} / \mathrm{l}$ $\left(10^{-5} \%\right)$. The histological analysis of a one-year-old carp that lived in an aquarium with a constant concentration of PHMG at $0.5 \mathrm{mg} / \mathrm{l}$ for 12 days showed that concentrations of an order of magnitude smaller $-0.01 \mathrm{mg} / \mathrm{l}\left(10^{-6} \%\right)$ is absolutely safe to consider. Chronic intoxication of fish caused by sublethal doses of PHMG leads to the development of numerous disorders in the liver, kidneys, and spleen, and to the inflammation of the pancreatic islets.

A comparative analysis of the toxicity of PHMG for microand macroorganisms does not allow us to state that the latter are less sensitive to this xenobiotic. So far, there are not enough convincing reasons to believe that the mechanisms of action of PHMG on pro and eukaryotic cells are fundamentally different. At the same time, the binding of PHMG molecules to suspended particles in water, organic and inorganic impurities, flocculation, and biodegradation by microorganisms leads to a rapid decrease of free active molecules of this biocide in aquatic ecosystems.

Keywords: polyhexamethylene guanidine, aquatic ecosystems, hydrobionts, toxicity, histological studies

\footnotetext{
*Corresponding author. Email: lysycya@ukr.net
} 


\section{INTRODUCTION}

Recently, polymeric derivatives of guanidine or polyalkylene guanidines (PAGs) have been increasingly used in composition of disinfectants and antiseptics. Among them, the most common are various salts of polyhexamethylene guanidine (PHMG) and polyhexamethylene biguanidine (PHMB). These polycations have a high bactericidal, virucidal, and fungicidal activity. Bactericidal concentrations of PHMG and PHMB in aqueous solutions are $0.001-1.0 \%$ (bacteriostatic from $0.0001-0.005 \%$ and higher), for mycobacteria tuberculocidal $0.5-4.0 \%$, virucidal $0.0001-0.5 \%$, and fungicidal 0.05-4.0\% (Moore et al., 2008; Oule et al., 2008; Koffi-Nevry et al., 2011; Feng et al., 2011; Mathurin et al., 2012; Prasanthi et al., 2012; Lysytsya, Mandygra, 2014). As a rule, in practice concentration of the active ingredient (PHMG) from $0.1 \%$ to $2.0 \%$ is used for disinfection.

In our study, the main attention was paid to the salts of PHMG. According to the IUPAC classification, the name of PHMG hydrochloride is poly (iminocarbonimidoylimino-1,6hexanediyl), monohydrochloride (CAS: 9140350-8, RN: 57029-18-2), but "polyhexamethylene guanidine hydrochloride" is used more often.

Despite clearly defined biocidal properties, PAGs are not chemically aggressive and are considered relatively safe for humans, animals, and ecological systems (Oule et al., 2012; Chakraborty et al., 2014; Mashat, 2016), although the latter statement is not indisputable and requires further verification. First of all, this is due to insufficient knowledge of the mechanisms of the biocidal action of PAGs. The most common point of view is the membrane-active mechanism of their action. A number of studies indicate that the polycation molecules irreversibly bind to the phospholipids of the cytoplasmic membrane (CPM) and, at bacteriostatic concentrations, change its ion permeability and transmembrane electrical potential. When bactericidal, they cause perturbation of the lipid bilayer and destruction of the CPM (Timofeeva, Kleshcheva, 2011; Zhou et al., 2011; Carmona- Ribeiro, de Melo Carrasco, 2013; Choi et al., 2017).
It should be noted that in their structure membranes of bacteria significantly differ from the CPM of most eukaryotic cells. First, attention is drawn to a different phospholipid composition. Negatively charged or "acidic" lipids (phosphatidylserine, phosphatidylinositol, phosphatidylglycerol, cardiolipin) predominate in the external lipid monolayer of bacteria, which causes a negative electrical potential on the cell surface. For understandable reasons, this greatly facilitates the adsorption of polycations of PHMG and PHMB to the membrane surface. In eukaryotic cells, acidic lipids are practically absent and various zwitterions (phosphatidylcholine, phosphatidylethanolamine, sphingomyelin) are available in an external lipid monolayer. Therefore as a rule the surface of the CPM, is positively charged, which, theoretically, must hinder the adsorption of polymeric guanidine derivatives and make these cells less sensitive to disinfectants.

According to another version (Chindera et al., 2016), polycation molecules penetrate the cell and bind firmly to the bacterial chromosome (polyanion), which is not protected by the nuclear membrane. Inactivation of bacterial DNA is the main cause leading to the death of the microorganism. In eukaryotic cells, drug molecules are isolated in endosomes and cannot enter the nucleus. As an additional argument, the authors cite an example of cationic antimicrobial peptides (AMPs), which are an important constituent of innate immunity. Such a mechanism (endosomes) protects host cells, primarily their DNA and RNA, from endogenous AMPs and, possibly, from other polycations, including PHMG and PHMB. It should be noted, though, that the damage to chromosomes, as one of the possible mechanisms of biocidal action of PHMB, is also described for eukaryotes of Leishmania major (Firdessa et al., 2015).

One way or another, but with the use of salts of PHMG in the composition of disinfectants the probability of their uncontrolled entry into natural ecosystems, including water bodies, is not ruled out. If we proceed from the above-mentioned possible mechanisms of biocidal action of PHMG, then it can be assumed that bactericidal 
concentrations of the preparation (at least $10^{-4}$ $10^{-3} \%$ ) should be low-toxic for higher organisms. Although the maximum permissible concentration (MPC) for PHMG chloride in water is set at $0.1 \mathrm{mg} / 1\left(10^{-5} \%\right)$, the potential hazard of this drug for hydrobionts has not been adequately studied. The study of this issue is of interest for both ecology and fisheries.

The purpose of our work was to determine the toxic concentrations and possible negative consequences of the use of disinfectants containing PHMG for freshwater fauna. Another task was to determine the histological changes in the tissues of fish in the chronic action of this xenobiotic.

To determine the potential negative impact of the PHMG on individual representatives of the fauna of aquatic biocenoses, a series of aquarium experiments were conducted using various classes of hydrobionts as test objects.

\section{MATERIALS AND METHODS}

The test objects were the following: infusorians Paramecium caudatum, flatworms Dendrocoelum lacteum, crustaceans Daphnia magna, mollusks Lymnaea palustris, fish guppies Poecilia reticulate Peters (young fish with a body weight of 1.7-2.2 g), and carp Cyprinus carpio. In C. carpio, both 3-day-old larvae and oneyear-old carp weighing 30-50 g were involved in the experiments.

The hydrobionts contained in groups of $10-$ 50 individuals in standard laboratory aquaria with a volume of $10-100 \mathrm{dm}^{3}$ (aeration was used for fish). The duration of illumination was up to 10-12 hours a day, the water temperature was from $20^{\circ} \mathrm{C}$ to $25^{\circ} \mathrm{C}$, $\mathrm{pH}$ was $6.5-7.5$. Infusorians were kept in Petri dishes on a nutrient medium (decoction of hay). Fish was daily fed with live feed Tubifex tubifex, the amount of which was fixed and estimated to be about 10$15 \%$ of the biomass, or dried daphnia.

The following salts of polyhexamethylene guanidine were used in the experiments: PHMG hydrochloride (PHMGhl), PHMG valerate (PHMGv), PHMG maleate (PHMGm), PHMG succinate monosubstituted (PHMGsm), and disubstituted (PHMGsd) synthesized at PE Termite (Rivne, Ukraine). The average molecular weights of polymers were in the range from 1 to $10 \mathrm{kD}$, the presence of low-molecular impurities did not exceed $0.5 \%$, the $\mathrm{pH}$ of aqueous solutions was 6.5-7.5. Preparations of PHMG were diluted with deionized water to the initial working concentrations of 10.0 or $1.0 \%$ (by weight), dosed in, slowly mixing, into aquariums with hydrobionts (Petri dishes for infusorians). The final concentrations of PHMG, taking into account the dilution, were $10^{-6}-10^{-2} \%$ (or 0.01 to $100 \mathrm{mg} / \mathrm{l}$ ), which corresponds to molar concentrations from $\approx 7 \times 10^{-8}$ Mole $/ \mathrm{dm}^{3}$ to $7 \times 10^{-4} \mathrm{Mole} / \mathrm{dm}^{3}$. The time for monitoring the state of test objects was up to 12 days.

In the experiments on acute toxicity, preparations of PHMG were added into aquaria once. In the experiments with the one-year-old carp, the content of the preparation in the aquarium water was monitored daily and maintained at a constant level of $5 \times 10^{-5} \%$ for 12 days in the study of the prolonged effect of sublethal doses of PHMGhl (chronic toxicity).

The concentration of PHMG in water was determined by the colorimetric method using the indicator eosin $\mathrm{H}$ (1,3,6,8-tetrabromo-fluorescein), which forms coloured compounds with shades from orange to intensely pink with PHMG salts (Vointseva, Gembitsky, 2009). A photoelectric calorimeter KFK-2 was used; the optical density was determined not later than $10 \mathrm{~min}$ after introducing the indicator (eosin $\mathrm{H}$ ) into the test sample at a wavelength of $540 \mathrm{~nm}$ using a cuvette with a thickness of 50 or $10 \mathrm{~mm}$. The result of the analysis was taken as the arithmetic mean of three parallel measurements, the relative error $\pm 5 \%$, and the confidence interval of 0.95 . The sensitivity of the method makes it possible to determine the PHMG content in water in the range $10^{-5}$ $10^{-4} \%$ without preliminary concentration.

For the histological examination, pieces of liver, spleen, kidney, and other organs of experimental fish were selected (Golovina, Bauer, 2007). Samples were placed in a $10 \%$ neutral formalin solution, fixed for one month. Cameral processing of the histological samples was per- 
formed in the laboratory of ichthyopathology of the Institute of Fisheries of the National Academy of Agrarian Sciences of Ukraine, according to recommendations and using specially developed equipment (Lesnikov, Chimarjova, 1987; Kozii, 2009). Light-optical studies of cells and tissues were carried out in transmitted light using the equipment Biolar-RU PZO (Poland), a halogen illuminator Linvatec-2 (USA) with a nominal power of $10-240 \mathrm{~W}$. the micropreparations were contrasted with a multigrade filter "FGPM$2.5 \mathrm{X}$ " and a correction filter "MONOCHROM 2.5X" (Russia). General morphometric studies of tissue structures were performed using a builtin eyepiece micrometer. Microphotographs of the histosections were performed with a digital camera "Nikon D-60" (Austria), using a 1.6x trinocular nozzle (Russia) and a computer-aided exposure detector "Minolta-EK" (Japan). Correction processing of the obtained micrographs was carried out with the help of computer programs "Adobe Photoshop CS 2", "Microsoft Office Picture Manager", and "FS Viewer".

Biometric studies of tissues were performed in accordance with generally accepted procedures. The obtained material was processed by the method of variational statistics with an emphasis on errors in the mean values, and with the help of the application package "Microsoft Excel".

\section{RESULTS}

In the case of infusorians of $P$. caudatum the action of different salts of PHMG was compared for their acute toxicity. Testing showed that at the concentration of $0.1 \%$, any of the test salts of PHMG caused quick death of protozoa during the first minute. Therefore in subsequent experiments the PHMG salts were taken at the concentration of $0.01 \%$. Based on the results obtained, the death rate was calculated and the results are shown in Table 1.

As can be seen from the table, PHMGhl and PHMGsd had the most toxic action : the mass death of unicellular animals occurred as early as during the first 5-10 min. Observations carried out with the use of light-optical methods showed that when the preparations of PHMG were added to the habitat of infusorians, an increased motor activity was first recorded. A few minutes later, the protozoa were concentrated in groups of up to 5-10 cells, then lost mobility and subsequently settled singly to the bottom of the Petri dish. The infusorians that died were round. At the same time, no traces of any appreciable destruction of cytoplasmic cell membranes in a light microscope $(\times 400)$ were observed.

In a negative gradation of toxicity, various samples of PHMG were located in this order: PPMGhl > PHMGsd > PHMGsm > PHMGv $\geq$ PHMGm. PHMG hydrochloride was the most reactive to $P$. cadatum reagent was: it also had the highest bactericidal activity (Lysytsya et al., 2015). The direct toxic effect of the drug on the infusorians is fixed when its concentration in the solution is from $10^{-3} \%$ and higher. In concentrations of $10^{-7}-10^{-4} \%$, preparations of PHMG had no noticeable negative effect on unicellular organisms. In this case, it must be

Table 1. Mortality of infusorians of $\boldsymbol{P}$. caudatum in an experiment on acute toxicity

\begin{tabular}{|c|c|c|c|c|c|c|}
\hline \multirow{2}{*}{ PHMG salt, conc. $0.01 \%$} & \multicolumn{6}{|c|}{ Death rate in time, $\%$} \\
\hline & $1 \mathrm{~h}$ & $2 \mathrm{~h}$ & $4 \mathrm{~h}$ & $8 \mathrm{~h}$ & $24 \mathrm{~h}$ & $36 \mathrm{~h}$ \\
\hline PHMGhl & $95 \pm 5$ & 100 & 100 & 100 & 100 & 100 \\
\hline PHMGsd & $80 \pm 5$ & 100 & 100 & 100 & 100 & 100 \\
\hline PHMGsm & $20 \pm 3$ & $20 \pm 3$ & $40 \pm 3$ & $50 \pm 3$ & $90 \pm 5$ & 100 \\
\hline PHMGv & 0 & $10 \pm 2$ & $10 \pm 2$ & $20 \pm 3$ & $50 \pm 3$ & $70 \pm 5$ \\
\hline PHMGm & 0 & $10 \pm 2$ & $10 \pm 2$ & $20 \pm 3$ & $50 \pm 3$ & $70 \pm 5$ \\
\hline Control & 0 & 0 & 0 & 0 & 0 & 0 \\
\hline
\end{tabular}

$P \leq 0.1$ 
taken into account that the actual concentration of the preparation in water was approximately twice lower than theoretically calculated when it was added to the samples. This is due to the fact that when the drug was added, there was an interaction (coagulation, flocculation) of a certain part of its molecules with suspended particles, organic and inorganic substances, and bacteria. It is obvious that the saturation of the growth medium of infusorians with these components reduced the concentrations of active molecules of PHMG and served as a kind of "toxicity buffer".

Proceeding from the fact that the most pronounced biocidal effect was typical of PHMGhl, in the subsequent experiments with different test objects only this preparation was used. The test reagent was added to the aquariums with hydrobionts once.

The effect on mollusc $L$. palustris was as follows: concentrations of PHMGhl $10^{-5} \%$ and lower according to the results of observations of up to 12 days did not cause noticeable changes in the behaviour of test objects, especially their death. Concentration of $10^{-4} \%$ in the first hours caused increased motor activity - molluscs tried to leave the aquarium and get out. During the next two days, the mobility of the molluscs significantly decreased; 7 to 12 days after the beginning of the experiment, all molluscs remained alive. The concentration of $10^{-3} \%$ caused the death of almost all the molluscs during the first day, the concentration of $10^{-2} \%$ caused a $100 \%$ death within the first $20-50 \mathrm{~min}$ after the application of the drug. Thus, it can be concluded that, for L. palustris the lethal concentration of PHMGhl LC $100=100 \mathrm{mg} / \mathrm{l}$ (or $10^{-}$ $2 \%$ ), and not active concentration $\mathrm{LC}_{0}=1 \mathrm{mg} / \mathrm{l}$ (or $10^{-4} \%$ ).

Regarding D. lacteum worms, the following results were obtained: the concentration of PHMGhl $10^{-5} \%$ practically did not cause noticeable changes in the behaviour of flatworms. In the first days, the concentration of $10^{-4} \%$ did not noticeably affect the change in the population size, but after 6-7 days after the beginning of the experiment deaths of up to $40-50 \%$ of the planaria were observed. The concentration of $10^{-3} \%$ caused the death of almost all worms during the first day; the concentration of $10^{-2} \%$ led to the death of all planaria within the first 20-30 minutes after the application of the drug. Therefore we assume that for $D$. lacteum $\mathrm{LC}_{100}=100 \mathrm{mg} / \mathrm{l}\left(\right.$ or $\left.10^{-2} \%\right)$, and $\mathrm{LC}_{0}=0.1 \mathrm{mg} / \mathrm{l}$ (or $10^{-5} \%$ ).

The concentration of PHMGhl $10^{-3} \%$ caused the death of half of the daphnia crustaceans 8-10 hours after the addition, and $100 \%$ death in 16 hours. An order of magnitude lower concentration of the preparation $10^{-4} \%$ led to complete death of the crustaceans in 2-3 days. Only at the initial concentration of the drug, $10^{-5} \%$, there was no significant change in the number of D. magna during the seven days of observation.

The effect of PHMGhl on guppy fish showed that the concentration of $10^{-3} \%$ (or $10.0 \mathrm{mg} / \mathrm{l}$ ) led to the death of fish within 1-2 hours. The concentration of the drug in the aquarium water of $10^{-4} \%$ and higher caused the death of all $P$. reticulate during the first day, and $10^{-5} \%$ did not lead to any changes in the behaviour or abundance of fish during the 12 days of observation. The summarized results of exposure of various concentrations of PHMGhl to test objects are given in Table 2.

The chronic action of PHMGhl on a oneyear-old carp for 12 days at a constant concentration of the drug in the aquarium water

Table 2. The effect of PHMGhl on selected species of gidrobionts

\begin{tabular}{c|c|c}
\hline Test object & $\begin{array}{c}\mathbf{L C}_{\mathbf{1 0 0}}, \mathbf{m g} / \mathbf{l} \\
(\%), \text { during } \\
\text { first 24 hours } \\
\text { of observa- } \\
\text { tion }\end{array}$ & $\begin{array}{c}\text { LC }_{\mathbf{0}}, \mathbf{m g} / \mathbf{l}(\%), \\
\text { duration of ob- } \\
\text { servations from 5 } \\
\text { to 12 days }\end{array}$ \\
\hline P. caudatum & $100\left(10^{-2}\right)$ & $1.0\left(10^{-4} \%\right)$ \\
\hline L. palustris & $100\left(10^{-2}\right)$ & $1.0\left(10^{-4} \%\right)$ \\
\hline D. lacteum & $100\left(10^{-2}\right)$ & $0.1\left(10^{-5}\right)$ \\
\hline D. magna & $10.0\left(10^{-3}\right)$ & $0.1\left(10^{-5}\right)$ \\
\hline P. reticulate & $1.0\left(10^{-4}\right)$ & $0.1\left(10^{-5}\right)$ \\
\hline $\begin{array}{c}\text { C. carpio } \\
\text { (3-day-old } \\
\text { larvae) }\end{array}$ & $5.0\left(5 \times 10^{-4}\right)$ & $0.125\left(1.25 \times 10^{-5}\right)$ \\
\hline
\end{tabular}


of $5 \times 10^{-5} \%$ (or $0.5 \mathrm{mg} / \mathrm{l}$ ) led to the death at the end of the observation term (from 7 to 12 days), eight fish out of 30 experimental, i.e., $\approx 1 / 4$ of the sample. The control group of ten individuals remained unchanged.

Histological studies showed the following: at the micro level of the parenchyma of the liver of individuals exposed to PHMGhl, various abnormalities were recorded, which is characteristic when chemical factors act on the body. The range of these changes included various compensatory adaptive reactions of the organ, disorders of blood microcirculation (haemorrhage and plasmorrhage), dystrophic changes in the form of vacuolization of the cytoplasm of hepatocytes, and granular dystrophy. Observations showed that the toxicological effect in the liver was most often manifested in the form of hypertrophy of hepatocytes. In this case, not only an increase in cell size, but also an increase in the size of the nucleus was observed (Fig. 1). Conditions: hematoxylin Böhmer, fuchselin Hart (in modification), oil immersion, increase $\times 900$.

It can be seen from the figure that in a number of cases the increase in the size of the cell and nucleus is accompanied by an increase in the number of nucleoli. It is known that one of the peculiar manifestations of morphofunctional adaptation is dedifferentiation of cells, which at the light-optical level is fixed simul-

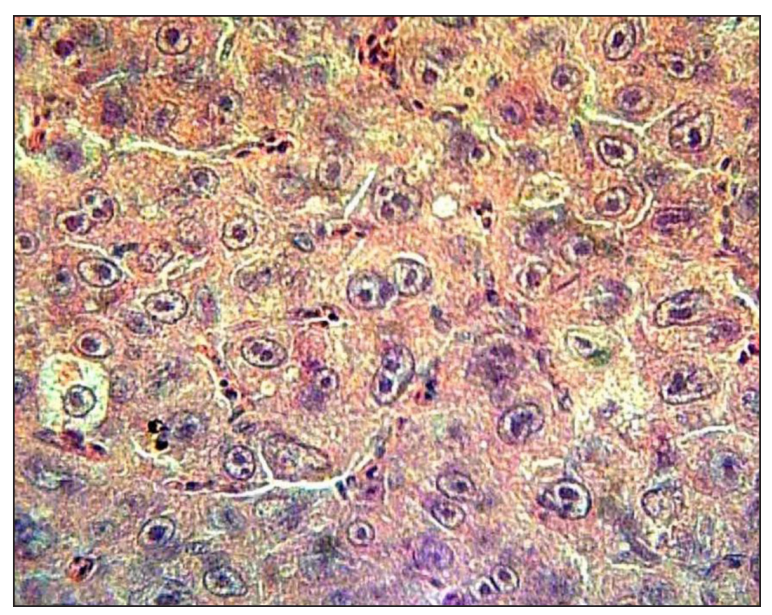

Fig. 1. Carp liver parenchyma. The medial zone. Hypertrophy of hepatocytes as a result of the action of PHMGhl taneously in the norm and under the action of damaging agents. It should be emphasized that early, compensatory changes in liver cells are almost indistinguishable from individual adaptation transformations of tissues and their constituents. Figure 1 reflects the process of the hypertrophy of hepatocytes, differs from the "boundary states" by some deformation of the nuclear contour and the local presence of granulation in the cytoplasm, which can be interpreted as the initial stage of the manifestation of a toxicological effect.

Similarly, one of the first signs of pathological changes in the liver can be attributed to microcirculation disorders. The manifestation of this category of anomalies in the liver of fish was of a many-sided character, but venous plethora and stasis were most often detected at the lightoptical level. The latter represent a stoppage of blood flow, which occurs as a result of stagnant plethora provoked by the influence of the toxicant (Fig. 2). Conditions: hematoxylin Böhmer, fuchselin Hart (in the modification), $\times 400$.

Expansion of the cavity of the hepatic vein due to the filling of its lumen with the blood cells can be clearly seen in Fig. 2 .

It should be pointed that in addition to these symptoms, the development of haemorrhage and plasmorrhage took place in individual specimens of dead fish (Fig. 3). Conditions: hematoxylin Böhmer, fuchselin Hart (in the modification), $\times 400$.

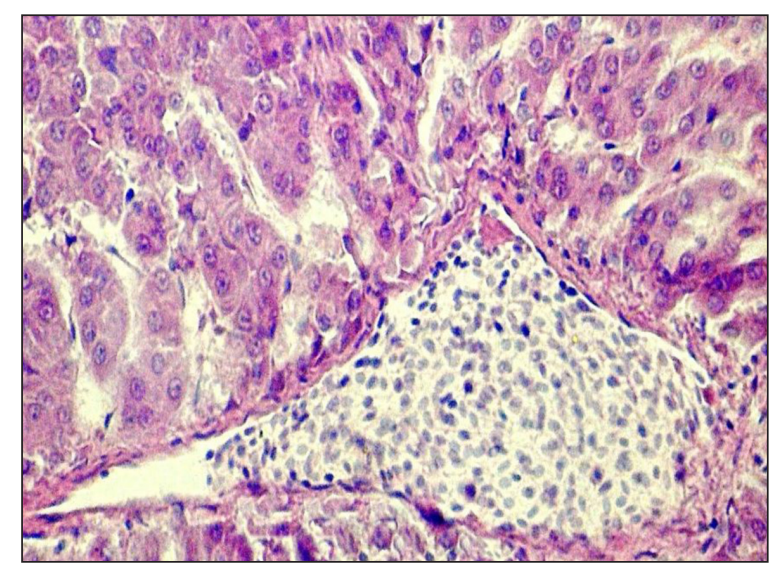

Fig. 2. Carp liver parenchyma. The medial zone. Venous plethora due to the action of PHMGhl 


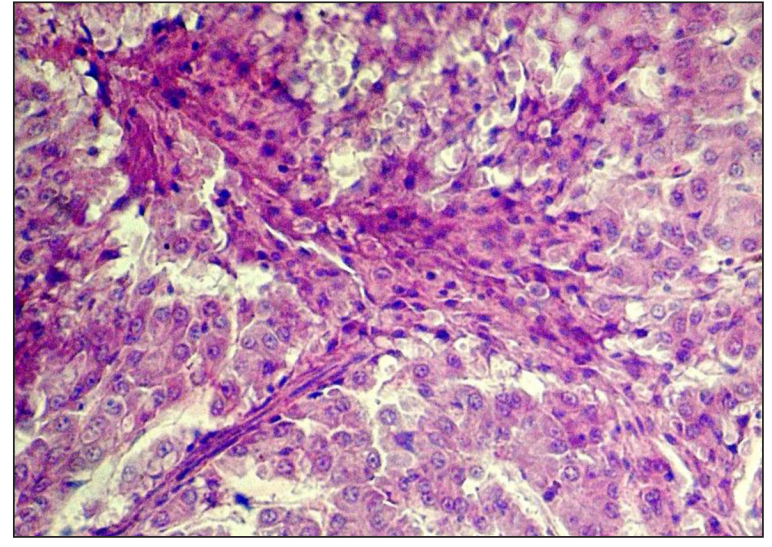

Often, hemodynamic disorders of the body combined with the pathology of the cellular structure, which manifested itself in dystrophy, and subsequently in necrosis of the parenchyma. It is known that in the norm and in conditions of moderate loads on aquatic ecosystems, the fish liver is characterized by considerable reactivity in combination with a reserve of functional ability. Under the conditions of high concentrations of water-soluble toxicants, the liver function fails, which is morphologically defined mostly as dystrophy. It has been experimentally established that pathological changes of this nature in the liver capture predominantly parenchymal structures. As a rule, in the pathology of the liver of experimental fish, we observed granular and hydrophylic (cellular disproteinosis) dystrophy. With granular dystrophy, hepatocyte sizes exceeded the norm, the cytoplasm of the cells was light, uniformly granular (Fig. 4). Conditions:

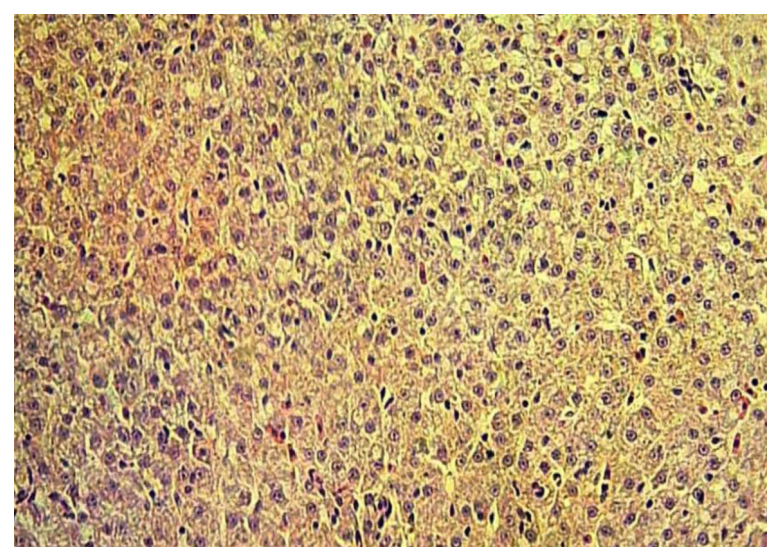

Fig. 4. Carp liver parenchyma. The medial zone. Granular dystrophy
Fig. 3. Carp liver parenchyma. The medial zone. Plasmorrhage

hematoxylin Böhmer, fuchselin Hart (in modification), $\times 100$.

Parameters of the nucleus as a whole corresponded to the norm, but it could be shifted to the periphery of the hepatocyte. The specific granularity of the cytoplasm is due to the appearance of a significant number of anomalously large mitochondria, as well as the deposition of protein secretion in the pathologically enlarged cisterns of the endoplasmic reticulum. The aggravation of the course of granular dystrophy naturally led to the appearance of hydropic dystrophy (Fig. 5). Conditions: hematoxylin Böhmer, fuchselin Hart (in modification), oil immersion, $\times 700$.

As can be seen from Fig. 5, a characteristic feature of changed hepatocytes is the presence in the cytoplasm of the optical cavities, which makes the contents of the cell seem transparent. We established that the cytoplasmic remains with a small amount of granularity are

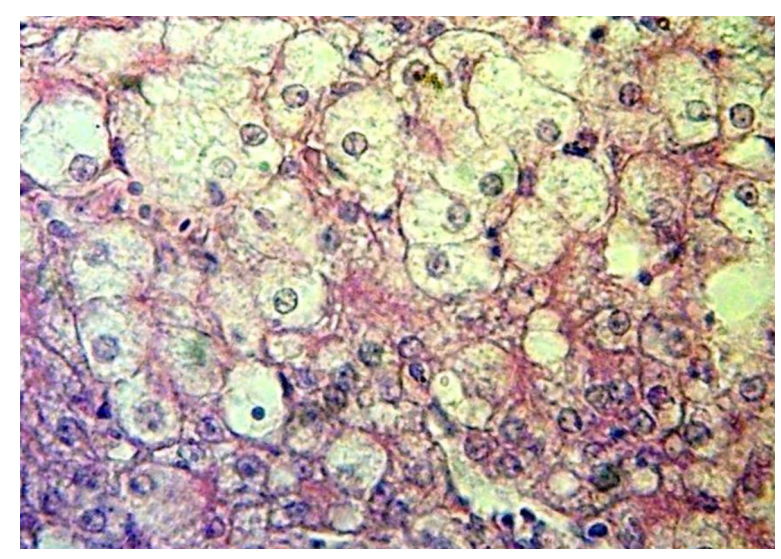

Fig. 5. Carp liver parenchyma. The medial zone. Hydropic dystrophy 
concentrated near the nuclei, more often along the cell membranes. Compared with the above case, the cells were voluminous, the contours of the plasmoleme were fairly distinct. Nuclei are characterized by poorly expressed polymorphism, weakly basophilic, with chromatin condensation. A remarkable feature of the hydropic dystrophy figure was the ability of the transformed hepatocytes to be located singly or in groups among normal cells.

Fish dissection was carried out selectively once in two days during the whole observation period. Histological studies revealed changes in other internal organs, in particular:

- in the kidneys, there were numerous cellular proliferates that formed around the vessels, glomeruli and tubules; proliferates consisted of histiocytes and lymphoid cells; cellular infiltrates first manifested themselves in the form of small foci, and later captured large areas of organs; renal tubules under the pressure of cellular infiltrates atrophied, the epithelium became low, cubic, or was in the state of granular and fatty distrophy; cell proliferates in some places sprouted into the tubules and formed cell cylinders in the lumens; sclerosis and hyalinosis developed in the glomerulus; in general, the picture of atrophy with subsequent destruction of blood vessels was observed in the kidneys;

- in the spleen, the expansion of blood vessels and diffuse hemorrhages were observed;

- in the pancreas, an inflammation of pancreatic islets was observed.

\section{DISCUSSION}

Analyzing the obtained experimental material and taking into account the literature data, it can be stated that the $0.01 \%$ concentration of PHMGhl is lethal for almost all aquatic organisms. Fish, ciliates, worms, daphnia and molluscs die in the shortest possible time - during the first minutes and hours. The concentration of $10^{-3} \%$ is acutely toxic - almost all objects of the study died within the first day. Concentration of the drug $10^{-4} \%$ (or $1 \mathrm{mg} / \mathrm{l}$ ) can be considered severely toxic. At the $10^{-5} \%$ (or $0.1 \mathrm{mg} / \mathrm{l}$ ) concentration of PHMGhl in water, there was no significant adverse effect of the drug on the population size and the behaviour of the hydrobionts studied by us during the entire observation time. This value corresponds to the MPC norm in the water of natural reservoirs. At the same time, taking into account the results of the chronic action of PHMGhl on one-year-old carp, it is still reasonable to consider the environmental safety limit of the preparation to be $10^{-6} \%$ (or $\left.0.01 \mathrm{mg} / \mathrm{l}\right)$ in water.

The fact of how much more the stability of molluscs responded to the action of the drug can, in our opinion, be explained by the fact that their body is covered with a kind of protective mucosa consisting mainly of mucin. Mucin is a specific mixture of compounds, the main component of which is glycoproteins. It also contains minerals, allantoin, collagen, elastin, and glycolic acid. According to the data (Marin et al., 2000), this complex of biologically active substances helps to protect the surface of the body of the mollusc, the rapid regeneration of damaged tissues and the formation of a shell. There exists information that even in higher vertebrates mucin secretions of the mucous glands also significantly reduce the bactericidal activity of PAGs: for example, $0.25 \%$ mucin concentration in the test sample reduced the bactericidal activity of PHMG relative to Staphylococcus aureus by four times (Ansorg et al., 2003). We believe that this is due to the ability of the acidic polysaccharides in the glycoproteins mucin to interact with the positively charged imino groups of the polycation, neutralize them and thereby neutralize the biocidal effect of PHMG or PHMB. In our case, hyalinosis was observed in fish with chronic action of PHMG in the kidneys, i.e., mucoids could partially neutralize the toxicant.

In this context, it is also worth pointing to the fact that microorganisms that are part of biofilms are less susceptible to PHMG than when they are in the form of suspensions (Mandyhra, 2014). Acid mucopolysaccharides of bacterial biofilms at neutral $\mathrm{pH}$ values have a negative charge due to the presence of carbox$y l$ or sulfate groups. This allows partial neutralizing of the activity of the polycation of PHMG. 
It should be noted that for natural reservoirs, an important factor is the adsorption of polycationic PAGs on various components of contaminated water (suspended and colloidal particles, dissolved organic and inorganic substances, oil products, surface active substances, etc.), which, in their majority, are anionic in nature. As a result, the initial concentration of PAGs decreases rather quickly, they are removed from the water, passing to the bottom phase, where the processes of their natural biological decomposition are significantly accelerated by the action of microorganisms of the activated sludge. Practice shows that PHMG solutions prepared on natural river water and on drinking (or distilled) water have different bactericidal effects. As a rule, river water contains a considerably larger amount of salts and suspended particles, which help to reduce the toxicity (activity) of the drug.

It is interesting that in our experiments with ciliates it was also noted that the salts of PHMG with succinic acid have a comparatively fast biocidal effect, but in low concentrations $\left(10^{-5}-10^{-4} \%\right)$ show a contrary stimulating effect. On days 3-5, the number of protozoa increased. Probably, this is due to a positive effect on the saprophytic bacterial microflora (one of the food sources for infusorians). In this case, PHMG acts as an additional source of nitrogen. There is evidence that individual microorganisms are able to include PAGs in the metabolic process, for example, Pseudomonas putida (O'Malley et al., 2006). This type of bacteria is often present in the soil or in sediment (silt) of water bodies. Such microorganisms contribute to the rapid degradation of PAGs in ecosystems.

Concerning the possible stimulating effect of PAGs, there are also data obtained on fish guppies (Ignatyk et al., 2010). In the concentration of PHMG $10^{-4} \%$ during seven days of observation, the drug stimulated the production and energy parameters of young individuals of $P$. reticulate, but after 14 days these values sharply decreased. At the same time, concentrations of $10^{-7}-10^{-6} \%$ (or $0.001-0.01 \mathrm{mg} / \mathrm{l}$ ) after seven days from the beginning of the experiment stimulated an increase in the specific growth rate of fish by more than $60 \%$ compared to the controls.
After 14 days, the growth rate (specific growth rate, feed conversion efficiency, optimality index) decreased, but still exceeded the control group. The authors suggested that the stimulating effect is associated with the adaptation syndrome (stress), which eventually should end in the phase of exhaustion (progressive toxicosis).

The histological studies of one-year-old carp that died because of the chronic action of PHMGhl allowed us to establish the absence of fatty dystrophy of hepatocytes. In this case, the question of the death of fish and the violation of the organ function with a certain kind of dystrophy is natural. In fact, the same (or almost identical) degeneration of carp cells is not evidence of a decrease in the functional activity of the hepatic parenchyma as a whole, as evidenced by the survival of most individuals within the same aquarium. Obviously, the severity of the flow of the process is not reflected by the light-optically observed difference in the ratio between the norm and the pathology, since in this case there is a different degree of damage to the ultrastructural constituents of the hepatocyte. Consequently, the circumstance of different survival of individuals can be interpreted as a discrepancy between minor violations of organ function and tangible morphological shifts.

Thus, it has been established that in the case of chronic action on the body of carp, PHMGhl has a pronounced toxic effect even in moderate concentration $\approx 5 \times 10^{-5} \%(5 \mathrm{mg} / \mathrm{l})$. In the liver, the drug caused disorders of blood microcirculation (haemorrhage and plasmorrhagia), hepatocyte hypertrophy, and granular and hydropic dystrophy of hepatocytes. In the kidneys, there were signs of atrophy with subsequent destruction of the vessels, sclerosis and hyalinosis developed in the glomerular compounds. In the spleen, the dilatation of blood vessels and diffuse haemorrhage were noted.

These results correlate with other researchers on changes in liver metabolism during the adaptation of fish in herbicide contamination of water bodies (Zhidenko et al., 2012).

In this context, it is also interesting to consider the toxic effects of PHMGhl on the human body. Cases of people poisoning as a result of 
ingestion of alcohol-containing drugs "Juniper" and "Crystal" intended for external use (Brusin, 2007) in the Russian Federation (Chelyabinsk, in 2006) have been described. The composition of these drugs included PHMGhl, diethylphthalate, and ethyl alcohol (92\%). The most typical manifestation of acute poisoning was cholestatic hepatitis (Ivashkin, Buyeverov, 2007; Ostapenko et al., 2011). The development of toxic hepatitis was accompanied by significant disturbances in the metabolism of lipids (Makarov, Ryasenskii, 2009). Immunohistochemical and ultrastructural studies of the liver showed proliferation and granulomatous response of mononuclear-macrophage link cells, an increase in the size of lysosomes, accumulation of a hard-to-metabolize material of high electron density in the lysosomes and phagolysosomes, a violation of the functions of Kupffer cells (tissue macrophages of the liver) (Friss et al., 2010). Pigmented nephrosis developed in the kidneys. Macroscopically, it manifested itself in dark strips on the incision of the kidney, microscopically - as impregnation of the tubal nephrothelia with pigment, nephrothelial necrosis, and the formation of pigmented cylinders. Although, in our opinion, in this case it is impossible to exclude the influence on patients' chronic alcohol intoxication.

\section{CONCLUSIONS}

The results obtained on the test objects can be legitimately extrapolated to natural freshwater ecosystems. The MPC for PHMGhl at the level of $0.1 \mathrm{mg} / \mathrm{l}\left(10^{-5} \%\right)$ is justified. At the same time, the results of studying the chronic toxic effect of the drug on the body of one-year-old carp indicate that the threshold of safety for hydrobionts and natural hydrocenoses should still be considered to be concentrations lower by an order of magnitude, i.e., $10^{-6} \%$.

The chronic effect of sublethal doses of the drug on the fish organism causes a number of pathological changes in the organs and tissues. Among them, attention is first of all drawn to the following: in the liver - blood microcirculation disorders (haemorrhage and plas- morrhage), hepatocyte hypertrophy, granular and hydrophilic dystrophy of hepatocytes; in the kidneys - atrophy with subsequent destruction of the vessels, in the joints of the glomeruli sclerosis and hyalinosis; in the spleen - dilated blood vessels and diffuse haemorrhages; inflammation of pancreatic islets.

At the same time, there are compensatory mechanisms that allow reducing the negative impact of PHMG on hydrobionts in water ecosystems. Because of good solubility in water when entering water bodies, working (biocidal) concentrations of the drug are diluted hundreds of thousands of times. Suspended particles, dissolved organic and inorganic substances, colloids, surface-active substances, etc., bind and neutralize some of the PHMG molecules. As a result of flocculation and settling in the bottom sediments, the amount of the drug dissolved in water decreases. Saprophytes of silt actively metabolize it and minimize the possibility of further xenobiotic migration through food chains.

Therefore, it can be considered that for the fishing industry, including pond fish, the use of PAGs in the disinfection of fishing gear, special equipment or implements is not a threat as these preparations do not represent a significant threat for hydrobionts. However, it does not exclude the need for selective environmental monitoring.

The results of the studies do not allow us to state that PAGs are much less toxic for macroorganisms than for prokaryotes as most manufacturers of disinfectants claim. Biocidal properties are manifested at the same concentrations, ranging from $10^{-4} \%$ and higher. Nor does the theoretical analysis of data on the mechanisms of biocidal action of PHMG on pro- and eukaryotic cells provide convincing arguments in favour of the fact that these mechanisms are fundamentally different. Therefore, it is advisable to continue studying the biochemical and biophysical features of the action of PHMG on pro- and eukaryotic organisms.

Received 31 May 2017 Accepted 13 September 2017 


\section{References}

1. Ansorg R, Rath PM, Fabry W. Inhibition of the anti-staphylococcal. Arzneimittelforschung. 2003; 53(5): 368-371. doi: 10.1055/s-00311297121.

2. Brusin KM. The use of the molecular adsorbent recirculating system in case of acute hepatic failure, caused by disinfectant poisoning. Clin Toxicol. 2007; 45(4): 360.

3. Carmona-Ribeiro AM, de Melo Carrasco LD. Cationic antimicrobial polymers and their assemblies. Int J Mol Sci. 2013; 14: 9906-46. doi:10.3390/ijms14059906.

4. Chakraborty B, Pal N, Maiti PK, Patra SK, Ray R. Action of newer disinfectants on multidrug resistant bacteria. J Evol Med Dent Sci. 2014; 3(11): 2797-813. doi: 10.14260/ jemds/2014/2211.

5. Chindera $\mathrm{K}$, Mahato $\mathrm{M}$, Sharma AK, Horsley H, Kloc-Muniak K, Kamaruzzaman NF, Kumar S, McFarlane A, Stach J, Bentin T, Good L. The antimicrobial polymer PHMB enters cells and selectively condenses bacterial chromosomes. Sci Rep. 2016; 6: 23121. doi: 10.1038/srep23121.

6. Choi H, Kim KJ, Lee DG. Antifungal activity of the cationic antimicrobial polymer-polyhexamethylene guanidine hydrochloride and its mode of action. Fungal Biol. 2017; 121(1): 53-60. DOI: 10.1016/j.funbio.2016.09.001.

7. Feng L, Wu F, Li J, Jiang Y, Duan X. Antifungal activities of polyhexamethylene biguanide and polyhexamethylene guanide against the citrus sour rot pathogen Geotrichum citri-aurantii in vitro and in vivo. Postharvest Biol Technol. 2011; 61(2-3): 160-4. doi: 10.1016/j.postharvbio.2011.03.002.

8. Firdessa R, Good L, Amstalden MC, Chindera K, Kamaruzzaman NF, Schultheis M, Röger B, Hecht N, Oelschlaeger TA, Meinel L, Lühmann T, Moll H. Pathogen- and hostdirected antileishmanial effects mediated by polyhexanide (PHMB). PLoS Neglected Tropical Diseases. 2015; 9(10): 1-22. doi: 10.1371/ journal.pntd.0004041.
9. Friss SA, Karaulovsky AN, Kosarev DN, Kostin EF, Milchenko IV, Saprykin KA, Orishich AN, Sorokin MG, Tarabtsev MV, Trifonov AG. [The electronic-microscopic research of kupher's cells at the poisoning spirit solution of the polyhexamethylenguanidine hydrochloride. Medical examination problems.] 2010; 10(1-2): 18-20. Available at: http://izh.sudmed.ru/jurnal/2010-01.pdf. Russian.

10. Golovina NA, Bauer ON. [Ichthyopathology.] Moscow: Mir; 2007: 92-108. Russian.

11. Ignatyk AA, Gavrikova VS, Chumak VL. The influence of polyhexamethylenegyanidine on bioproduction parameters of young fish. Research Bulletin of NTUU “KPI". 2010; 3: 16-20. Available at: http://old.bulletin.kpi.ua/ files/2010-3-3.pdf. Ukrainian.

12. Ivashkin VT, Buyeverov AO. The toxic hepatitis caused by alcohol substitutes poisoning. Russian Journal of Gastroenterology, Hepatology, Coloproctology. 2007; 17(1): 4-8. Available at: http://www.gastro-j.ru/files/s1_1277626040. pdf. Russian.

13. Koffi-Nevry R, Manizan AL, Tano K, Bi YCY, Oulé MK, Koussemon M. Assessment of the antifungal activities of polyhexamethylene-guanidine hydrochloride (PHMGH)based disinfectant against fungi isolated from papaya (Carica papaya L.) fruit. Afr J Microbiol Res. 2011; 24(5): 4162-9. Available at: http://www.academicjournals.org/journal/ AJMR/article-full-text-pdf/5B83A1314755.

14. Kozii MS. [Assessment of the current state of histological techniques and ways to improve the study of ichthyofauna.] Kherson: Oldiplus; 2009. 310 p. Russian.

15. Lesnikov VA, Chimarjova TV. [Pathological and histological analysis of the state of fish in field and experimental toxicological studies. Methods of ichthyologic research.] Moscow: Nauka; 1987. 80-1. Russian.

16. Lysytsya A, Mandygra M. The antiviral action of polyhexamethyleneguanidine derivatives. J Life Sci. 2014; 8(1): 22-6. Available at: http:// www.davidpublishing.org/show.html?16401. 
17. Lysytsya AV, Mandygra YM, Bojko OP, Romanishyna OO, Mandygra MS. [Differential sensitivity of microorganisms to polyhexamethyleneguanidine.] Mikrobiologichny zhurnal. 2015; 77(5): 11-9. Available at: http:// www.imv.kiev.ua/images/doc/MBJ/2015/ UMJ_05_2015.pdf. Ukrainian.

18. Makarov VK, Ryasenskii DS. [Assessment of effects produced by taking in polymethyleneguanidine hydrochloride on lipid composition of blood serum.] Toksikologicheskii vestnik. 2009; 3: 18-21. Available at: http://toxreview. $\mathrm{ru} /$ magazine/?c4a=20170100. Russian.

19. Mandyhra YM. [Bactericidal efficiency of "epidez" on microorganisms that form biofilms.] Veterinarna medicina. 2014; 99: 41-43. Available at: http://jvm.kharkov.ua/sbornik/99/1_11.pdf. Ukrainian.

20. Marin F, Corstjens P, de Gaulejac B, de VrindDe Jong E, Westbroek P. Mucins and molluscan calcification. Molecular characterization of mucoperlin, a novel mucin-like protein from the nacreous shell layer of the fan mussel Pinna nobilis (Bivalvia, pteriomorphia). J Biol Chem. 2000; 275(27): 20667-75. doi: 10.1074/ jbc.M003006200.

21. Mashat BH. Polyhexamethylene biguanide hydrochloride: features and applications. Br J Environ Sci. 2016; 4(1): 49-55.

22. Mathurin YK, Koffi-Nevry R, Guéhi ST, Tano K, Oulé MK. Antimicrobial activities of polyhexamethylene guanidine hydrochloride-based disinfectant against fungi isolated from cocoa beans and reference strains of bacteria. J Food Prot. 2012; 75(6): 1167-71. doi: 10.4315/0362-028X.JFP-11-361.

23. Mikodina EV, Sedova MA, Chmilevsky DA, Mikulin AE, Pjanova SV, Poluektova OG. [Histology for ichthyologists: experience and advice.] Moscow: Publishing house VNIRO; 2009. 112 p. Russian.

24. Moore LE, Ledder RG, Gilbert P, McBain AJ. In vitro study of the effect of cationic biocides on bacterial population dynamics and susceptibility. Appl Environ Microbiol. 2008; 74(15): 4825-34. doi: 10.1128/AEM.00573-08.
25. O’Malley LP, Collins AN, White GF. Biodegradability of end-groups of the biocide polyhexamethylene biguanide (PHMB) assessed using model compounds. J Ind Microbiol Biotechnol. 2006; 33(8): 677-84. doi:10.1007/ s10295-006-0103-6.

26. Ostapenko YN, Brusin KM, Zobnin YV, Shchupak AY, Vishnevetskiy MK, Sentsov VG, Novikova OV, Alekseenko SA, Lebed'ko OA, Puchkov YB. Acute cholestatic liver injury caused by polyhexamethyleneguanidine hydrochloride admixed to ethyl alcohol. Clin Toxicol (Phila). 2011; 49(6): 471-7. doi: $10.3109 / 15563650.2011 .592837$.

27. Oule MK, Azinwi R, Bernier AM, Kablan T, Maupertuis AM, Mauler S, Nevry RK, Dembélé K, Forbes L, Diop L. Polyhexametylene guanidine hydrochloride-based disinfectant: a novel tool to fight methicillin-resistant Staphylococcus aureus and nosocomial infections. J Med Microbiol. 2008; 57(12): 1523-38. doi: 10.1099/jmm.0.2008/003350-0.

28. Oule MK, Quinn K, Dickman M, Bernier AM, Rondeau S, Moissac D, Boisvert A, Diop L. Akwaton, polyhexamethylene-guanidine hydrochloride-based sporicidal disinfectant: a novel tool to fight bacterial spores and nosocomial infections. J Med Microbiol. 2012; 61: 1421-7. doi: 10.1099/jmm.0.047514-0.

29. Prasanthi K, Murty DS, Saxena NK. Evaluation of antimicrobial activity of surface disinfectants by quantitative suspension method. International Journal of Research in Biological Sciences. 2012; 2(3): 124-127. Available at: https:// urpjournals.com/tocjnls/27_12v2i3_8.pdf.

30. Timofeeva L, Kleshcheva N. Antimicrobial polymers: mechanism of action, factors of activity, and applications. Appl Microbiol Biotechnol. 2011; 89(3): 475-92. doi: 10.1007/ s00253-010-2920-9.

31. Vointseva II, Gembitsky PA. [Polyguanidines - disinfecting agents and multifunctional additives to composite materials.] Moscow: LKM-press; 2009. 303 p. Russian.

32. Zhidenko AO, Bibchuk KV, Poletaj VM, Krivopisha VV. [The value of fish liver metabolism 
indicators for adaptation to the conditions of herbicide contamination.] Naukovii visnik Chernivets'kogo universitetu. Biologiya. Biologichni sistemi. 2012; 4(4): 433-7. Available at: http://ibhb.chnu.edu.ua/uploads/files/vb/ BS_T4_V4_2012.pdf. Ukrainian

33. Zhou Z, Zheng A, Zhong J. Interactions of biocidal guanidine hydrochloride polymer analogs with model membranes: a comparative biophysical study. Acta Biochim Biophys Sin (Shanghai). 2011; 43(9): 729-37. doi: 10.1093/ abbs/gmr067.

\section{Andriy Lysytsya, Natalya Matvienko, Mihail Kozii, Alexander Aishpur \\ GUANIDINO POLIMERINIŲ DERIVATŲ PO- VEIKIS HIDROBIONTAMS}

\section{Santrauka}

Daugelyje pasaulio šalių guanidino polimeriniai derivatai yra aktyviai naudojami kaip dezinfektantai ir antiseptikai. Poliheksametileno guanidinas (PHMG) ir poliheksametileno biguanidinas (PHMB) yra tipiški šios klasès junginių atstovai. Eksperimentų metu buvo tiriamas toksinis PHMG druskų poveikis ìvairių rūšių ir klasių hidrobiontams. Nustatyta, kad saugi vienkartinio poveikio PHMG koncentracija vandenyje yra $0,1 \mathrm{mg} / 1\left(10^{-5} \%\right)$. Vienerių metų karpių, 12 dienų gyvenusių akvariumuose su pastovia 0,5 mg/l PHMG koncentracija, histologinè analizè rodo, kad visiškai saugia laikytina mažesnè koncentracija - 0,01 mg/l (10-6\%). Žuvų lètinè intoksikacija, nulemta subletalinių PHMG dozių, sukelia daugybinius kepenų, inkstų, blužnies sutrikimus, taip pat kasos uždegimą.

Raktažodžiai: poliheksametileno guanidinas, vandens ekosistemos, hidrobiontai, toksiškumas, histologiniai tyrimai 